\title{
Invited Response on: Adipose Tissue in Multiple Symmetric Lipomatosis Shows Features of Brown/Beige Fat
}

\author{
Daniel Schiltz $^{1} \cdot$ Stephan Schreml $^{2}$ (1)
}

Received: 28 October 2021 / Accepted: 29 October 2021/Published online: 15 November 2021

(C) The Author(s) 2021

Level of Evidence $V$ This journal requires that authors assign a level of evidence to each article. For a full description of these Evidence-Based Medicine ratings, please refer to the Table of Contents or the online Instructions to Authors http://www.springer.com/00266.

Dear Xinhang Dong et al.,

Thank you very much for your thoughts on this study [1]. The hematoxylin-eosin staining of affected and unaffected fatty tissue in patients suffering from MSL showed increased inflammatory infiltration as compared to control fatty tissue of healthy patients. However, we found that overall there was no difference between affected and unaffected tissue in MSL patients (although macrophages were not counted). These results are consistent with those obtained by CD200 and UCP1 immunohistochemistry. Evaluation of table 1 was subjective, as we do not have an automated (objective) quantification. This is a limitation of the study. We thank the authors for the elaboration on the different types of macrophages (especially M2-type) that have different phenotypic characteristics and biological functions. Further evaluation regarding M2 macrophages would be a current and interesting topic for further research in our patient cohort.

Stephan Schreml

stephan.schreml@ukr.de

1 Department of Plastic, Hand- and Reconstructive Surgery, University Hospital Regensburg, Regensburg, Germany

2 Department of Dermatology, University Hospital Regensburg, Franz-Josef-Strauss-Allee 11, 93053 Regensburg, Germany
Funding Open Access funding enabled and organized by Projekt DEAL. The study was funded by the German Research foundation DFG (grant SCHR 1288/5-1).

\section{Declarations}

Conflict of interest The authors declare that they have no conflicts of interest to disclose.Human and Animals ParticipantsThis article does not contain any studies with human participants or animals performed by any of the authorsInformed ConsentFor this type of study informed consent is not required

Open Access This article is licensed under a Creative Commons Attribution 4.0 International License, which permits use, sharing, adaptation, distribution and reproduction in any medium or format, as long as you give appropriate credit to the original author(s) and the source, provide a link to the Creative Commons licence, and indicate if changes were made. The images or other third party material in this article are included in the article's Creative Commons licence, unless indicated otherwise in a credit line to the material. If material is not included in the article's Creative Commons licence and your intended use is not permitted by statutory regulation or exceeds the permitted use, you will need to obtain permission directly from the copyright holder. To view a copy of this licence, visit http://creativecommons. org/licenses/by/4.0/.

\section{Reference}

1. Schiltz D, Tschernitz S, Ortner C et al (2020) Adipose tissue in multiple symmetric lipomatosis shows features of brown/beige fat. Aesth Plast Surg 44:855-861. https://doi.org/10.1007/s00266-02001666-6

Publisher's Note Springer Nature remains neutral with regard to jurisdictional claims in published maps and institutional affiliations. 